China Perspectives

2019-1 | 2019

Touching the Proverbial Elephant: The Multiple Shapes of Chinese Law

\title{
The 2018 Constitutional Amendments
}

Significance and Impact on the Theories of Party-State Relationship in China

\section{Feng Lin}

\section{(2) OpenEdition}

\section{Journals}

Electronic version

URL: http://journals.openedition.org/chinaperspectives/8646

DOI: $10.4000 /$ chinaperspectives.8646

ISSN: 1996-4617

\section{Publisher}

Centre d'étude français sur la Chine contemporaine

Printed version

Date of publication: 20 March 2019

Number of pages: 11-21

ISSN: 2070-3449

\section{Electronic reference}

Feng Lin, «The 2018 Constitutional Amendments », China Perspectives [Online], 2019-1 | 2019, Online since 19 March 2020, connection on 19 December 2020. URL : http://journals.openedition.org/ chinaperspectives/8646; DOI : https://doi.org/10.4000/chinaperspectives.8646

(C) All rights reserved 


\title{
The 2018 Constitutional Amendments
}

\author{
Significance and Impact on the Theories of Party-State Relationship in China*
}

\author{
FENG LIN
}

\begin{abstract}
The 2018 constitutional amendments in China have attracted strong criticism both at home and abroad. This paper first uses contextual, historical, and empirical analysis to examine whether the three major amendments are as bad as widely perceived, and whether or not they will have a significant impact on actual constitutional practice in China. The paper then analyses how the constitutional amendments may challenge the two existing theories on Chinese constitutionalism. The paper argues that although none of the constitutional amendments will have any practical importance, they do send out a very negative signal, and that the trend of a constitutionalised fused system demands at least revision of the existing theories and possibly a new theory, for the purpose of not only justifying Chinese constitutional practice but also leading China towards at least a thin rule of law.
\end{abstract}

KEYWORDS: Constitutional amendment, China, Party-state relationship, term limit, leadership of the Communist Party of China, Supervisory Commission, political constitutional theory, dual normative system.

\section{Introduction}

$\mathrm{T}$ he National People's Congress (NPC) of China adopted the fifth batch of amendments to the 1982 Constitution (the Constitution) on 11 March 2018, 14 years after the Constitution was last amended. (1) Unlike all previous amendments, which attracted very positive comments, the 2018 amendments have generally been criticised by scholars and commentators both in mainland China and overseas. ${ }^{(2)}$ Among these amendments, three important ones have received wide attention. The first is the incorporation of the leadership of the Chinese Communist Party (CCP) into Article 1 of the Constitution as "the defining feature of socialism with Chinese characteristics." The second is the constitutional recognition of no term limits for the "tripartite rule" of the Secretary-General of the CCP, the President of State, and the Chairman of the Central Military Commission (CMC) through the abolition of term limits on the President of State. The third is the creation of a new constitutional organ called the supervisory commission to consolidate certain functions of the CCP's Discipline and Inspection Commissions (DICS), the people's procuratorates, and the Ministry of Supervision under the State Council.

The main criticism of these amendments is that they represent a significant setback to China's constitutional development because term limits for senior state officials, including the president, and separation of the CCP from the state are regarded as major achievements of the 1982 Constitution. ${ }^{(3)}$ The first issue this article will examine is whether the three major amendments are really as bad as widely perceived, by using contextual, historical, and empirical analysis of how those issues have been dealt with by the Constitution, and whether or not those constitutional amendments will have a significant impact upon actual constitutional practice in China. The discussion will show that leadership of the CCP has been consistently emphasised and practiced in China, and that term limits have never been imposed on the Chairman of the CMC, who is de facto the country's most powerful person. This paper therefore argues that the first two constitutional amendments are unlikely to have any practical impact. However, the creation of the supervisory com- missions means a new constitutional power has been created, which will change not only the constitutional structure under the people's congress system but also the Party-state relationship under the Constitution.

As far as the Party-state relationship is concerned, various interpretative frameworks have been proposed with the aim of developing a coherent constitutional theory to justify China's Party-state system. The political constitutional theory and dual normative system theory are the most wellknown among them. The political constitutional theory argues that the CCP, as the ruling political party in China, should not be subject to the constraints of the written Constitution (Chen 2008; Jiang 2010; Jiang 2014). The dual normative system theory argues in essence that there is a separation of political authority from administrative authority, of the CCP apparatus from the state apparatus, and of the CCP normative system from the state normative system (Backer 2012; Li 2015). Whether the creation of the new constitutional organ of supervisory commissions as the second fused organ within both the CCP and state apparatus will affect the applicability of these two theories is the second issue this paper will explore. The supervisory commissions wear two hats and perform dual functions within both the CCP and the state from the national to the local levels, and the 2018 reform of the CCP and state organs has combined more CCP and state organs. (4) They combine to challenge the persuasiveness of the two theories.

* This article is the output of the research project entitled "Constitutionality of Demand for Hong Kong Independence -A Comparative and Jurisprudential Study," funded by the UCC of the HKSAR Government (GRF No. 9042592). The author would like to thank the two anonymous reviewers for their valuable and constructive comments on the draft of this paper. The author would also like to thank Dr. Fei Mengtian, my postdoc research fellow, for helping me standardise the footnotes in this paper.

1. The 1982 Constitution was last amended in 2004

2. Many constitutional scholars have criticised the amendments in WeChat groups, as they cannot do so through official media or publications.

3. See Frank Ching, "China Charter Revision Shows HK Future Hangs by a Thread," Hong Kong Economic Journal, 5 April 2018, A13.

4. “深化党和国家机构改革方案” (Shenhua dang he guojia jigou gaige fang'an, Plan on deepening the CCP and state institutional reform), Central Committee of the CCP press release, 21 March 2018, http://www.gov.cn/zhengce/2018-03/21/content_5276191.htm\#1 (accessed 29 January 2019). 
Section I of this article first provides a review of the 2018 constitutional amendments. While the abolition of term limits for the President of State and the incorporation of the leadership of the CCP into Article 1 of the Constitution have attracted wide media attention both in mainland China and overseas, ${ }^{(5)}$ many amendments are caused by and related to the creation of a new constitutional supervisory organ, i.e., supervisory commissions at various levels. Section II moves on to discuss the practical significance of the constitutional amendments, especially the three mentioned above. Although the first two amendments have attracted wide media attention as well as strong criticism, this article argues that they do not really have much practical constitutional significance because they will not result in any change of current constitutional practice in China. They do, however, send unpopular messages. The creation of the constitutional supervisory organ brings a second merger of a CCP institution, i.e., the DIC, with two constitutional organs and makes another CCP organ a constitutional one. It is a constitutional endorsement of the CCP's functions. This amendment will not have any practical significance, either, because the DICs and supervisory organs under the State Council already worked as one unit before the 2018 constitutional amendments. However, it is likely to have major implications for both constitutional theory and the Party-state relationship in China.

Section III examines the possible impact of the creation of the supervisory commissions on two existing conceptual interpretative frameworks of Chinese constitutional reality. With regard to both the political constitutional theory and dual normative systems theory, this article will first discuss the theories themselves and then how each may be challenged by the 2018 constitutional amendments. In particular, the discussion will focus on how the applicability of the two theories is likely to be affected by the merger of the CCP and state organs and the new constitutional power of supervision resulting from the creation of the supervisory commissions. The last part of Section III will analyse whether a new theory is demanded by the 2018 constitutional amendments.

The paper concludes by arguing that none of the three controversial constitutional amendments will cause much practical change to constitutional practice in China, although they do send out a very bad signal that life-long presidency is returning. However, the creation of the constitutional organ of supervisory commissions merges another CCP organ with state organs and constitutionalises the functions originally performed by the DICs. This is the constitutional amendment that is likely to cause significant change to both the constitutional structure and its operation in China. This amendment also raises new constitutional issues such as the nature of the supervisory power, the relationship between supervisory commissions and other state organs, and so on. In addition, the third constitutional amendment together with the Supervision Law and the trend of fusion in 2018 pose challenges to the two theories on Chinese constitutionalism. While acknowledging the continuing applicability of political constitutional theory, the author argues that the theory has fundamental limitations by blindly endorsing any decisions taken by the CCP and should only be regarded as a theory suitable for present-day China, which is still in transition from rule by law to rule of law. With regard to the theory of a dual normative system, dualism as its core has been challenged by the 2018 constitutional developments in China. It has become less persuasive in explaining Chinese constitutional practice. The fact that China has moved closer to a constitutionalised fused system challenges political constitutional theorists in China to come up with a new theory that can better explain and/or justify new constitutional developments in China. Any new theory should serve not only the purpose of justifying constitutional practice in China but also the purpose of leading China towards at least a thin rule of law.

\section{The 2018 constitutional amendments and their significance}

\section{The 2018 constitutional amendments}

The NPC adopted 20 constitutional amendments to the 1982 Constitution on 11 March 2018. ${ }^{(6)}$ This is the fifth time the 1982 Constitution has been amended. (7) Unlike previous four times when the Constitution was amended, there was little consultation this time either before or after the CCP submitted its proposal for constitutional amendments to the NPC. ${ }^{(8)}$ Unlike the previous constitutional amendments, ${ }^{(9)}$ the 2018 constitutional amendments have attracted strong criticism from many scholars in mainland China, who are of the view that the amendments are a serious setback to China's constitutional development. ${ }^{(10)}$

The decision to amend the Constitution was first made by the Standing Committee of the Political Bureau of the Central Committee of the CCP (Politburo) on 29 September 2017. (11) Thereafter consultation was carried out within the CCP at a relatively high level. Consultation with non-CCP organisations didn't happen until 15 December 2017. The draft amendments were endorsed by the Central Committee of the CCP in its meeting on 1819 January 2018. The draft amendments were only made available to the general public on 26 January 2018, when the CCP submitted to the Standing Committee of the NPC (NPCSC) its recommendation to amend the Constitution. The draft amendments were first discussed by the NPCSC at its $32^{\text {nd }}$ meeting, held on 29-30 January 2018. Thereafter, the amendments were adopted by the NPC on 11 March 2018. There were less than two months from the time the draft amendments were made available to the public to the time they were adopted by the NPC. (12) It was the quickest amendment made to the 1982 Constitution, with little public consultation and strong criticism from scholars. ${ }^{13)}$

Among the 20 amendments, only the following relate to the rule of law and may affect the Party-state relationship. The first is amendment 32, which has changed "improve the socialist legal system" in paragraph 7 of the Preamble

\section{See Note 3 above}

6. They are numbered the $32^{\text {nd }}$ to the $51^{\text {st }}$ amendments to the 1982 Constitution.

7. After the current Constitution was enacted in 1982, it was amended four times in 1988, 1993, 1998 , and 2004 before the 2018 Amendments.

8. I have been told by some senior academics in China that they were informed through telephone calls by the relevant authorities not to comment on the draft constitutional amendment proposal.

9. Chinese scholars mainly supported the first four constitutional amendments to the 1982 Constitution.

10. In various electronic discussion forums, including Wechat groups, many Chinese scholars have expressed their concerns. But some scholars have said there is a policy prohibiting public discussion of the 2018 Constitutional amendments in mainland China. There are some articles that indirectly criticise the 2018 Constitutional Amendments. See for example, Gong Renren 龚刃韧, “梁漱溟与 孙冶方：中国宪法史上值得书写的两位人物” (Liang Shuming yu Sun Yefang: Zhongguo xianfa shi shang zhide shuxie de liang wei renwu, Liang Shuming and Sun Yefang: Two noteworthy characters in Chinese constitutional history), FT zhongwen wang (FT 中文网), 7 February 2018, http://www.ftchinese.com/story/001076252 (accessed 30 January 2019).

11. See Explanation made by Mr. Wang Chen on Constitutional Amendments (draft), “王晨作宪法修 正案 (草案) 的说明" (Wang Chen zuo xianfa xiuzheng'an (cao'an) de shuoming, Wang Chen making explanations on the constitutional amendments (draft)), Fenghuang wang caijing 凤凰网财经, 7 March 2018, http://finance.ifeng.com/a/20180307/16014115_0.shtml (accessed 27 April 2018).

12. Ibid.

13. Ibid. 
to "improve the socialist rule of law." (14) The second is the addition of a new sentence to the end of the existing paragraph 2 of Article 1, which reads "[t]he leadership of the CCP is the defining feature of socialism with Chinese characteristics." ${ }^{15)}$ The third is that a new constitutional organ called supervisory commission has been created through several amendments. ${ }^{(16)}$ Supervisory commissions have been defined as the supervisory organs of the state. ${ }^{(17)}$ They are established at the national level as well as a various local levels. ${ }^{(18)}$ The $\mathrm{Na}$ tional Supervisory Commission (NSC) is the highest supervisory organ and directs the work of the supervisory commissions at various local levels. ${ }^{(19)}$ The NSC is accountable to the NPC and NPCSC. Supervisory commissions at the local levels are accountable to the organs of state power (the People's congresses) creating them and to the supervisory commissions at the immediately higher level. (20) Supervisory commissions exercise supervisory power independently according to the law, free from interference by any administrative organ, public organisation, or individual. They shall, in handling duty-related violations of law or crimes, cooperate with judicial organs, procuratorial organs, and law enforcement organs, with mutual checks and balances. ${ }^{(21)}$ The fourth is that paragraph 3 of Article 79 of the Constitution has been amended to read "both the President and the Vice-President of the PRC have a term of office the same as the term of the NPC." The two-term limit on the President of State has been removed from the original paragraph 3.

Out of the four major amendments relating to rule of law and the Partystate relationship, incorporating the CCP's leadership into Article 1 of the Constitution and the abolition of term limits on the President of State have attracted wide attention and criticism. There are altogether nine amendments relating to the creation of the new constitutional supervisory organ. (22) That is understandable, because once a new constitutional organ is established, its relationship with all existing constitutional organs needs to be defined in the Constitution. As a result, the relevant Articles of the Constitution need to be amended accordingly.

\section{The importance of the 2018 constitutional amendments}

\section{Inclusion of the leadership of the CCP in Article 1 of the Constitution}

One of the four cardinal principles incorporated into the Preamble of the 1982 Constitution is the insistence on the leadership of the CCP. ${ }^{(23)}$ The CCP has always insisted on its leadership ever since it came to power in 1949. (24) Its ruling style has, however, transformed over the years from that of a revolutionary party to a ruling party (Zhao 2010a: 430). One commentator has noted two specific transformations. First, the CCP has abandoned "the mass mobilisation and social transformation goals in favor of political stability and economic development" (ibid.: 430). Second, the CCP has changed from a vanguard into a more inclusive political party (ibid.). President Jiang Zemin's theory of "three represents" (san ge daibiao 三个代表), ${ }^{(25)}$ regarded as one major effort in this direction, was incorporated into the Preamble of the Constitution in 2004. (26) The key theme of the theory is that the CCP represents not only workers but also "the development of advanced productive forces, the orientation of advanced culture, and the fundamental interests of the broadest masses" (ibid.: 430). One Western reporter interprets the theory of "three represents" to mean that the CCP "can be all things to all people, promoting the interests not just of workers and farmers but of wealthy entrepreneurs as well." (27) The primary objective of the sec- ond transformation is considered a rebranding of the CCP to make it "more inclusive and less intrusive" (ibid:: 430).

Different views exist with regard to the normative effect of the incorporation of the leadership of the CCP into the Preamble. That's also the reason why different views exist on the importance of incorporation of the leadership of the CCP into Article 1 of the Constitution this time. From the perspective of comparative constitutional law, it has been noted that there are three kinds of preambles, including a ceremonial preamble, an interpretive preamble, and a substantive preamble (Orgad 2010: 722 note 52). If the Preamble to the Constitution is regarded as merely a ceremonial preamble, the insistence on the leadership of the CCP as contained in the Preamble would be of merely ceremonial value and wouldn't have any normative effect in practice. The incorporation of the leadership of the CCP into Article 1 in the 2018 constitutional amendments is therefore important because specific articles of the Constitution are binding. This view is, however, not shared by many constitutional scholars in China.

The prevailing view among Chinese scholars, especially constitutional scholars, is that the Preamble to the Constitution has the same legal effect as the articles of the Constitution (Yin and Li 2004; Chen 2008). Since the leadership of the CCP is already there in the Preamble, it won't make any difference including it again in Article 1 of the Constitution. Another point worthy of note is that the new constitutional amendment states expressly that the leadership of the CCP is a defining feature of socialism with Chinese characteristics. It means the leadership of the CCP has now become an essential component of socialism as defined and implemented in China.

In practice, the CCP has always been the ruling political party and has exercised its leadership role since coming to power in 1949. (28) Since the student movement at Tiananmen Square in 1989, the leadership of the CCP has been strengthened. At the national level, following his predecessors Jiang Zemin and $\mathrm{Hu}$ Jintao, the current Secretary-General of the Central Committee of the CCP, Xi Jinping, currently holds the positions of President of State and Chairman of the CMC. He is the most powerful person in China. This tripartite rule has been followed for more than two decades. ${ }^{(29)}$ At a local level,

14. See 2018 Constitutional Amendments.

15. This is amendment 36 of the $5^{\text {th }}$ Constitutional Amendments.

16. They include amendments $37,41,42,43,44,48,49,50$, and 52 of the $5^{\text {th }}$ Constitutional Amendments.

17. See Article 123 of 1982 Constitution (with 2018 Amendments).

18. See Article 124 of 1982 Constitution (with 2018 Amendments).

19. See Article 125 of 1982 Constitution (with 2018 Amendments).

20. See Article 126 of 1982 Constitution (with 2018 Amendments).

21. See Article 127 of 1982 Constitution (with 2018 Amendments).

22. They include amendments $37,41,42,43,44,48,49,50$, and 52 in the $5^{\text {th }}$ Constitutional Amendments.

23. See the Preamble of the 1982 Constitution.

24. See preambles to all four Constitutions of the PRC.

25. It means: the CCP has always represented the most advanced productivity and culture in China, as well as the most fundamental interests of the majority of the Chinese people.

26. It was added to para. 7 of the Preamble by the 2004 Constitutional Amendments.

27. Elisabeth Rosenthal, "China's Communists Try to Decide What they Stand for," The New York Times, 1 May 2002.

28. Some scholars have argued that the leadership of the CCP was insisted on and practiced well before the CCP took over governance in mainland China in 1949. See jiang Shigong (2010).

29. After Mao, tripartite rule started again in November 1989 when Deng Xiaoping gave up chairmanship of the Central Military Commission and passed it to jiang Zemin (that was five months after Jiang was elected Secretary General of the (CP). When Jiang stepped down from the position of President of State in March 2003, he didn't pass the chairmanship immediately to Hu Jintao. Instead, he kept that position until September 2004. 
the party secretary of the CCP organisation at each level of the people's government is already the number one person among all governmental officials at the same level, be it at the provincial, municipal, district/country, or township level. ${ }^{(30)}$ Hence, it is unlikely that incorporating the leadership of the CCP into Article 1 of the Constitution will make any practical difference at all. Accordingly, it will not be of any constitutional significance.

\section{Abolition of term limits for the President of State}

The rumour that the two-term limit for the President of State would be scrapped had circulated for quite some time before the official release of the draft constitutional amendments. ${ }^{(31)}$ When the proposal was out, it sparked fears of a dangerous return to one-man rule. ${ }^{(32)}$ In introducing the draft constitutional amendments to the NPC, Wang Chen, the deputy chief of the NPC, said that the draft amendments to remove term limits won unanimous support among all the people involved in the consultation process. ${ }^{(33)}$ Many commentators nevertheless have reservations about this. ${ }^{(34)}$

A constitutionally mandated two-term limit for senior state officials such as the Premier and President of State was introduced by the 1982 Constitution based on Deng Xiaoping's idea. ${ }^{(35)}$ The intention was to break through one-man rule. It has been argued that it was a mechanism to institutionalise China's leadership system in the 1980s, to address the lack of effective institutions, and to create checks on the arbitrary authority of the Mao years (Zhao 2010b: 425).

Many scholars and commentators are of the view that abolishing the term limit for the President of State is a drawback and a means for President $\mathrm{X}$ i to stay in power forever. That may lead to over-concentration of power in one person. For example, one commentator in Hong Kong has observed that it is "a dramatic rollback of one of Deng Xiaoping's major political reforms in the 1980s, in the wake of the death of Chairman Mao Zedong, whose one-man, 27-year rule had exacted a huge toll on China." (36) There were even warnings that the imperial system was being re-instated and that another Cultural Revolution was imminent. (37)

The opposite view is that abolition of the term limit on the President of State should be supported. The former head of the Central Policy Unit of the Hong Kong Government, Mr. Shiu Sin Por, has provided a few justifications. First, the move is clearly intended to bring the three posts, i.e., the President of State, Chairman of the CMC, and Secretary-Ceneral of the Central Committee of the CCP, under a consistent arrangement. ${ }^{(38)}$ Neither the Secretary-General of the CCP nor the Chairman of the CMC is subject to term limits. Second, under Xi's leadership in his first five years as President of State, China has undergone a great purge of corrupt officials, which has seriously destabilised the system and provides a new beginning for China's march towards clean and effective government. Given that the anti-corruption campaign is only in its first stage, Xi's leadership will ensure that the anti-corruption campaign will continue to its second stage of "not being able to be corrupt" and the third stage of "not wanting to be corrupt." (39) Third, "the next 10-15 years are crucial for China's development. Its political system is still young and evolving, and also faces complex internal as well as external challenges. China must build a system that is both effective and enduring. Abolition of the term limit of the President of State will contribute to a strong governing body and is consistent with China's needs." (40)

The legal issue is whether abolition of the term limit will have either theoretical or practical importance to China's constitutional design and prac- tice. Theoretically, many presidential systems, such as the US and South Korea, have term limits for their Presidents. ${ }^{(41)}$ But in countries adopting a parliamentary system such as the United Kingdom or Germany, there is no statutory term limit for a Prime Minister/Chancellor. It all depends on whether or not the Prime Minister/Chancellor can win the confidence of his political party and Parliament. ${ }^{(42)}$ The essence is whether there is a wellestablished system to ensure that the head of state actually has the confidence and support of the majority of people in that country. If the answer is yes, there are no strong theoretical justifications to limit his term. In the case of China, the bad experience with long-term one-man rule by Mao Zedong has convinced many people that it is necessary to have a term limit for the President of State.

Practically, the answer depends on whether President Xi's actual power to control will be affected if he no longer holds the position of President of State after his second term. According to the late Professor Xiao Weiyun, who was involved in drafting the 1982 Constitution, they drafted a longer chapter on the CMC under the 1982 Constitution. Their draft was submitted to Deng Xiaoping for comments. Deng deleted the other articles, and only two articles were kept. This has been confirmed by Wang Hanbin, the former vice chairman of the NPCSC. ${ }^{(43)}$ There is no term limit on the Chairman of the CMC, which may represent Deng's intention. ${ }^{(44)}$ Deng was the actual top leader in China because he held that position. After Deng, Jiang Zemin was still the de facto number one person after finishing his two terms as President of State because he continued to hold the position of Chairman of the CMC. ${ }^{(45)}$ Following the precedents of Deng and Jiang, one persuasive argument is that whoever holds the position of Chairman of the CMC will be the de facto number one leader in China. Hence, so long as Xi holds onto the position of Chairman of the CMC, he will continue to have actual control in China even without the position of President of State. Another justifica-

30. The Chinese Central Government raised this requirement in 1992. See Wu Zhantuan 吴展团, “党 委书记兼任人大主任有利于地方发展” (Dangwei shuji jianren renda zhuren youli yu difang fazhan, It is beneficial to local development if the Party Secretary and the chairman of local people's congress will be the same person), Hong wang 红网, 7 January 2016, http://ldhn.rednet.cn/c/ 2016/01/07/3882405.htm (accessed 24 July 2018).

31. The rumour was already circulating in 2017 in Hong Kong.

32. Nectar Gan, "Scrapping Term Limits 'has Wide Support'," South China Morning Post, 6 March 2018, A1.

33. Shi Jiangtao, "Report Tells How Move to Scrap Term Limit began," South China Morning Post, 6 March 2018, A4.

34. Ibid.

35. A two-term limit is also imposed on the Chairman of the NPCSC, the President of the Supreme People's Court, and the Chief Procurator of the Supreme People's Procuratoriate. See Articles 66, 120 , and 130 of the 1982 Constitution.

36. Frank Ching, "China Charter Revision Shows HK Future Hangs by a Thread," op. cit.

37. Shiu Sin Por, "Enduring System," South China Morning Post, 6 March 2018, A11.

38. Ibid.

39. Ibid.

40. Ibid.

41. For example, the US President has a two-term limit. The South Korean President has a one-term limit.

42. German Chancellor Angela Merkel is now in her fourth term.

43. It was Deng Xiaoping's view to have only the current two articles on the CMC. See Wang Hanbin (2012). For detailed discussion of the inclusion of the CMC into 1982 Constitution, see Chen Sixi 陈斯喜 and Liu Songshan 刘松山 (2001: 3-6).

44. This was stated by Professor Xiao Weiyun in a lecture delivered at the City University of Hong Kong many years ago. The official reason given by Professor Xiao in his book is that the CMC is different from other constitutional organs at the national level because it needs to deal with emergencies such as war. It is therefore better to have no term limit. See Xiao Weiyun 肖蔚云 (2004: 536).

45. Jiang only gave up the position as Chairman of the CMC about two years after Hu became President of State. 
tion for this argument is that the President of State has mainly been a ceremonial title without much substantive authority. ${ }^{(46)}$ This amendment seems more of an alignment of the three positions and is unlikely to have any substantial constitutional significance.

However, the fact that the President of State in China is not subject to periodic evaluation by voters in genuine periodic general elections as in a parliamentary system makes abolition of the term limit very undesirable. Further, the abolition of term limits on the President of State together with the emphasis on the leadership of the CCP will make life-long presidency easier to achieve, and will move China further away from rule of law at the constitutional level.

\section{Creation of a new constitutional organ - supervisory commissions}

Discussion of the creation of supervision commissions started with the proposal to reform the supervisory system in China in 2016 (Ma 2017). A related legislative task is to enact the Supervision Law of the PRC (the Supervision Law) (ibid.). The draft Supervision Law was only made available to the public in late 2017. ${ }^{(47)}$ The Supervision Law was enacted by the NPC during the same session as the 2018 constitutional amendments. Long before the draft Supervision Law was made public, some scholars who had been consulted by the central government in the drafting process strongly criticised the draft Supervision Law (Qin 2017a; Qin 2017b; Tong 2016). The new supervisory commissions will combine certain functions formerly performed by the DICs of the CCP, the people's procuratorates, and the administrative supervision departments under various people's governments. Once created, they will be very powerful constitutional organs. One main criticism raised by some scholars of the reform as well as of the draft Supervision Law is that such powerful constitutional organs should be subject to the supervision and control of the organs of state power, i.e., the people's congresses. In order to achieve that objective, the Constitution should be amended (Tong 2016). It was a surprise to those scholars that the 2018 constitutional amendments addressed this concern.

As discussed above, at the national level, the NSC will be another constitutional organ at the same level as the State Council, the Supreme People's Court, the Supreme People's Procuratorate, and the CMC. ${ }^{(48)}$ The implication is that state supervisory power will be regarded as a new kind of state power comparable to the executive, military, judicial, and procuratorial powers (Qin 2017a; Qin 2017b; Tong 2016).

Although neither the Constitution nor the Supervision Law provides a definition of supervisory power, Article 1 of the Supervision Law provides that its purposes are to (1) strengthen the supervision of all public officials exercising public power, (2) realise the full coverage of national supervision, (3) conduct anti-corruption work in an in-depth manner, and (4) promote the modernisation of the national governance system and governance capacity. ${ }^{(49)}$ According to this provision, the two main objectives are supervision of public officials in their exercise of public power, and performance of anti-corruption work. Article 11 of the Supervision Law has set out in detail the exact scope of supervisory power. ${ }^{(50)}$

There are a few issues worthy of detailed analysis about this new constitutional organ. The first is the nature of the supervisory commissions. When China's supervisory mechanism was re-established in the 1980s, administrative supervision was conducted by the Ministry of Supervision, while the
DICs of the CCP were in charge of supervising CCP members (Zhao 2010a: 166-70). In 1992, the Central Committee of the CCP and the State Council jointly decided to merge the DIC and administrative supervision organs at the same level. On 7 January 1993, the Central Discipline and Inspection Commission (CDIC) of the CCP and the Ministry of Supervision were merged. Soon after, a similar merger was carried out at the local levels nationwide (ibid: 170-1).

At the national level, the NSC has been established and its first chairman is Mr. Yang Xiaodu, one of eight deputy chairmen of the CDIC of the CCP. (51) The Chairman of the CDIC is Mr. Zhao Leji, one of seven members of the Standing Committee of the Politburo. ${ }^{(52)}$

Six out of the remaining seven vice chairmen of the CDIC are vice chairmen of the NSC. ${ }^{(53)}$ In addition, there are ten other members in the NSC, of which nine are members of the Standing Committee of the CDIC, and the last one is an ordinary member of the CDIC. ${ }^{(54)}$ In total, the NSC has 17 members, whereas the CDIC has 133 members. ${ }^{(55)}$ Although there is significant overlap of senior members between the CDIC and NSC, it is still possible to argue that the CDIC as a CCP organisation and the NSC as a state/constitutional organ are separate. That may well be the intention of the CCP for such an arrangement. ${ }^{(56)}$

At the operational level, the original Ministry of Supervision and the CDIC consist of the same group of people wearing two different hats. Mr. Yang Xiaodu, the Chairman of the NSC, was the Minister of Supervision. (57) With the establishment of the NSC, the original anti-corruption unit within the Supreme People's Procuratorate has been merged into the NSC. The working

46. According to articles 80 and 81 of the PRC Constitution, the President of the PRC promulgates statutes; appoints and removes the Premier, Vice-Premiers, State Councillors, Ministers in charge of Ministries or Commissions, and the Auditor-General and the Secretary-General of the State Council; confers state medals and titles of honour; issues orders of special pardons; proclaims martial law; proclaims a state of war; issues mobilisation orders; conducts state affairs; receives foreign diplomatic representatives on behalf of the People's Republic of China and, in pursuance of decisions of the Standing Committee of the National People's Congress, appoints and recalls plenipotentiary representatives abroad, and ratifies and abrogates treaties and important agreements concluded with foreign states. The only substantive authority among them is the authority to conduct state affairs, which was introduced by the 2004 constitutional amendments (the $28^{\text {th }}$ Constitutional Amendment).

47. Its late publication for public consultation indicates the concern of the central government that the draft law might be controversial, and that the government didn't want the public to discuss it for too long.

48. See Amendment 37 in the 2018 Constitutional Amendments.

49. See Article 1 of the Supervision Law of the PRC.

50. Article 11 of the Supervision Law of the PRC provides: "A supervisory commission shall, in accordance with the provisions of this Law and relevant laws, perform the duties of supervision, investigation, and disposition: (1) It shall provide integrity education to public officials, and conduct the supervision and inspection of public officials' performance of functions in accordance with the law, impartial exercise of power, clean administration, and moral integrity. (2) It shall conduct investigations of duty-related violations of laws and crimes such as suspected corruption and bribery, abuse of power, negligence of duty, power rent-seeking, tunnelling, the practice of favouritism and falsification, as well as the waste of state assets. (3) It shall, in accordance with the law, make decisions on disciplinary actions in respect of government affairs against public officials who violate any law, hold liable the leaders who fail to perform their functions in an effective manner or neglect their duties and responsibilities, transfer investigation results on suspected duty-related crimes to the people's procuratorates for examination and initiate a public prosecution in accordance with the law, and offer supervisory suggestions to the entities where supervisory objects work."

51. There are eight Vice-chairmen, and Mr. Yang is ranked number one out of them. See "领导结构” (Lingdao jiegou, Leadership structure), http://www.ccdi.gov.cn/xxgk/ldjg/ (accessed 30 April 2018).

52. The other members are Xi Jinping, Li Keqiang, Han Zheng, Wang Huning, Wang Yang, and Li Zhanshu.

53. They are Liu Jinguo 刘金国, Yang Xiaochao 杨晓超, Li Shulei 李书磊, Xu Lingyi 徐令义, Xiao Pei 肖培, and Chen Xiaojiang 陈小江. See http://www.ccdi.gov.cn/xxgk/ldjg/ (accessed 30 April 2018).

54. See http://www.ccdi.gov.cn/xxgk/ldjg/ (accessed 30 April 2018).

55. Ibid.

56. The advantage of doing so is to have clear separation of party organisations from constitutional organisations.

57. After establishment of the NSC, Mr. Yang became its first Deputy-chairman. 
staff of the NSC and the CDIC are the same. ${ }^{(58)}$ It is fair to say that the NSC and the CDIC have become the same organisation wearing two different hats, with the only differences being that a few senior leaders of the CDIC are not senior leaders of the NSC, and that most ordinary members of the CDIC are not members of the NSC. ${ }^{(59)}$

At the local levels, DICs of the CCP and administrative supervision departments of the people's governments at the same levels already consisted of the same group of personnel wearing two different hats. After the reform, as at the national level, the anti-corruption units of local people's procuratorates have been merged into local supervisory commissions. Local supervisory commissions and DICs at the same level have become the same organisations wearing two different hats. Before the reform, the head of a local supervisory department of a people's government was usually a deputy chairman of the local DIC at the same level. ${ }^{(60)}$ After the reform, the head of a local DIC concurrently holds the position of chairman of the supervisory commission at the same level of government. ${ }^{(61)}$

The above discussion of the evolution of institutional arrangements reveals that before the 2018 constitutional amendments, DICs were already part of the executive branch of the people's governments. Since the 2018 constitutional amendments, the DICs continue to exist within the constitutional structure. Their status has, however, been upgraded from an organ within the executive branch to a constitutional organ with equal status to the people's government, the people's court, and the people's procuratorate. ${ }^{(62)}$

The second is the scope of supervision to be conducted by supervisory commissions. Under the Administrative Supervision Law that has been abolished by the Supervision Law, ${ }^{(63)}$ the scope of supervision was limited to "the administrative organs of the state and public servants thereof and other persons appointed by administrative organs of the state." (64) Now the Supervision Law has expanded the scope comprehensively to include civil servants of all political parties and state organs, personnel of organisations and entities managing public affairs, managers of state-owned enterprises, personnel engaged in management at basic-level self-governing mass organisations, and personnel performing public duties according to law. ${ }^{(65)}$ This comprehensive supervision is supported by the statutory authorisation that supervisory commissions may dispatch supervisory bodies and supervisors to organs of the CCP, state organs, organisations and entities managing public affairs, administrative regions, and state-owned enterprises under their jurisdictions. ${ }^{(66)}$

This is a significant change. In addition to the original administrative supervision, state supervision now also covers supervision of CCP organs and their personnel, which used to be the function performed by the DICs of the CCP. State supervision also covers supervision of other political parties, organs of state power, state-owned enterprises, and autonomous mass organisations. In summary, all organisations and personnel involved in performing public functions in their broad sense fall within the scope of supervision by supervisory commissions. That is why Professor Tong Zhiwei has observed that it is a change from administrative supervision to comprehensive supervision (Tong 2016).

The third is the legalisation of certain extra-legal compulsory measures formerly taken by the DICs. One specific measure is "shuanggui" (双规), meaning that a DIC will detain an official/Party member who is suspected of corruption at a designated place and ask him to make a confession within a designated period of time (Sapio 2008; Backer and Wang 2014). This has been criticised by many scholars as an unlawful violation of the principle of presumption of innocence and other fundamental rights (Sapio 2008;
Backer and Wang 2014). Now Article 22 of the Supervision Law has granted supervisory commissions the authority to detain suspects of corruption under certain circumstances. ${ }^{(67)}$ The creation of the new constitutional organ of supervisory commissions together with the above statutory authorisation has not only legalised but also constitutionalised the formerly unlawful "shuanggui."

In summary, the 2018 constitutional amendments together with the Supervision Law have achieved several results. First, they have converted the CCP's disciplinary organs into state supervisory organs. Second, they have upgraded the status of the CCP's disciplinary organs within the constitutional structure from an organ of the executive branch to a constitutional organ at the same level with the executive branch, the people's courts, and the people's procuratorates. Third, the inclusion of all political parties within the scope of supervision will strengthen the impression that all political parties and their personnel are part and parcel of the governing structure in China and the same as other constitutional organs. ${ }^{(68)}$ These results have changed the constitutional structure of China, the relationship between different state powers, and the Party-state relationship.

\section{The impact on two conceptual interpretative frameworks}

Unlike scholars embracing normative constitutional theory who opine that China has a constitution but without constitutionalism (Zhang 2010a), some scholars in both mainland China and overseas have, for more than a decade, made efforts to put forward various conceptual interpretative frameworks to explain and justify constitutional practice in China, especially the divergence and conflicts between constitutional practice and the written Constitution (Xie and Patapan 2016: 1002-14). For example, most rights provisions exist on paper only, CCP organs operate outside the state legal system and exercise leadership in all national affairs, and so on (Lin 2010). This part of the article will examine two better-known theories of Chinese constitutionalism (Backer

58. This information was provided by an official working in the CDIC.

59. Many other ordinary members of the CDIC are leaders of provincial DICs. The practice is for two leaders from each provincial and ministerial DIC to be members of the CDIC.

60. The head of the local supervisory department within the people's government is usually the no. 3 person within the local disciplinary commission below the Chairman and Vice-chairman in charge of daily work. This information was obtained from two officials working in provincial and municipal people's governments in mainland China during the writing of this article.

61. This information was provided by local officials through my interviews.

62. In constitutional theory, the National Supervisory Commission is at the same level as the State Council, the Central Military Commission, the Supreme People's Court, and the Supreme People's Procuratorate.

63. See Article 69 of the Supervision Law of the PRC.

64. See Article 2 of the Administrative Supervision Law of the PRC.

65. See Article 15 of the Supervision Law of the PRC

66. See Article 12 of the Supervision Law of the PRC

67. Article 22 provides: "Where the person under investigation is suspected of corruption, bribery, neglect of duty, malfeasance in office, or any other serious duty-related violation or duty-related crime, and the supervisory organ has obtained facts and evidence on the violation or crime, but needs to conduct further investigation of important issues, after examination and approval by the supervisory organ in accordance with law, the person may be detained at a specific place under any of the following circumstances: (1) The circumstances of the case in which the person is involved are major or complicated. (2) The person may escape or commit suicide. (3) The person may make a false confession in collusion or forge, conceal, or destroy evidence. (4) The person may commit any other conduct that obstructs investigation. - The supervisory organ may, in accordance with the provision of the preceding paragraph, detain any person who is suspected of giving bribes or committing any joint duty-related crime. The setup, management, and supervision of detention places shall be governed by the relevant provisions of the state."

68. The Civil Servants Law of the PRC classifies those working in the organisations of all political parties as civil servants. See Articles 64 and 66 of the Civil Servants Law. 
2012; Chen 2008) and analyse whether they are capable of satisfactorily explaining the 2018 constitutional amendments, in particular the creation of new supervisory organs that fuse the CCP and state apparatus.

\section{Political constitutional theory and its applicability}

\section{The theory}

Some constitutional scholars started advocating political constitutionalism in China in 2008 (Chen 2008; Jiang 2010; Jiang 2014). Professor Chen Duanhong from Peking University Law School was the very first of them (Chen 2008). Other scholars joined him later, and Professor jiang Shigong has become better known overseas. ${ }^{(69)}$ Despite their criticisms, they believe that China has a constitutional system that has been functioning effectively for the past four decades. ${ }^{\left({ }^{70}\right)}$ Further, the Chinese political system has been a significant force in maintaining political order, keeping the country and society integrated, and developing its economy rapidly. ${ }^{(71)}$ While accepting that some aspects of Chinese political practice would appear unconstitutional in terms of the written Constitution, scholars of political constitutional theory try to explain and justify such inconsistencies.

Professor Chen defends the leadership of and the roles played by the CCP by resorting to the theory of sovereignty. For him, the CCP is not bound by the Constitution because it has sovereignty. It is the sovereign power to make the Constitution (pouvoir constituant), and is not subject to any restraints. When exercised, that sovereign power creates constituted powers (pouvoirs constitués) such as legislative, executive, and judicial powers. Since the Preamble to the Constitution states that sovereignty resides in the Chinese people, it is possible to regard the CCP and NPC as constituted powers. For Professor Chen, the CCP as ultimate representative of the people is sovereign (not pouvoirs constitués) and is therefore above the NPC. The CCP is a standing organisation and exists alongside the Constitution, rather than being bound by it. The CCP may exercise its sovereign power to take measures that are not in line with the written Constitution. Consequently, it makes little sense to regard those measures as unconstitutional, because the Constitution is not intended to bind the CCP as the sovereign (Chen 2008; Xie and Patapan 2016: 1009-12).

Professor jiang Shigong defends unconstitutional acts of the CCP through an alternative interpretation of the constitution. For him, the written constitution is only one aspect of a larger conception of the constitution, in which there exists no inconsistency between political practice and the constitution. He argues that in addition to the written constitution, there are other rules and provisions that govern Chinese politics, and which constitute an unwritten constitution or even the real constitution of China. According to him, it is a mistake to take the written constitution as the only constitution. Rather, the constitution is composed of a range of rules and practices that are influential in Chinese politics (Jiang 2010; Jiang 2014; Xie and Patapan 2016: 1011). Some other commentators call these the "living" constitution in China (He 2012). The constitution of the CCP is one type of unwritten constitution in China. ${ }^{(72)}$ The tripartite rule, the constitutional thoughts of political leaders, and laws and statutes of a constitutional nature are also important parts of the unwritten constitution in China (Jiang 2010).

What Professor Chen and Professor Jiang have in common is that both are of the view that the Constitution of the CCP constitutes valid and genuine constitutional rules that are binding in China, although based on different jurisprudential justifications.

\section{Analysis of its applicability}

How might each of them respond to the fusion of CCP and state organs through the new supervisory commissions and their inclusion within the Constitution? Chen might argue that it's the CCP's decision to carry out this fusion and make the new supervisory commissions accountable to the people's congresses. Such acts undertaken by the CCP as sovereign are perfectly fine and acceptable. Moreover, the NPC has endorsed such fusion through the 2018 constitutional amendments. As a result, the fusion is constitutional. For Jiang, the fusion is not a problem either. Since the fusion is already written into the Constitution, he doesn't even need to resort to his unwritten constitution theory to argue the constitutionality of the fusion. In essence, because scholars of political constitutional theory give decisions of the CCP a status either equivalent to or higher than the Constitution, and because whatever is written into the Constitution will be constitutional, the CCP's decision to carry out this fusion and incorporate it into the Constitution is not only constitutional but also perfectly acceptable to them.

The inclusion of the leadership of the CCP into Article 1 of the Constitution through the 2018 constitutional amendments suggests that the CCP is not satisfied with the existence of its leadership only in the Preamble of the Constitution and wants it to be part of its formal text. Two possible inferences can be drawn. One is that the CCP wants its leadership to become a formal constitutional principle in order to legitimise its actual leadership in all national affairs. The other is that it may be problematic to rely on the CCP constitution to govern the state and to treat the CCP constitution above the state Constitution. As a result, the political constitution theory is best regarded as a theory to justify Chinese constitutional practice that is still in transition. ${ }^{(73)}$

\section{The theory of a dual normative system and its applicability}

\section{The theory}

Although the term "dual normative system" was coined by Ling Li, the substantive argument was raised a few years earlier by Larry Backer in 2012 (Backer 2012). Like Professor Chen, Backer opines that the Chinese constitutional order is grounded on the distribution of popular sovereign power between the CCP and the administrative apparatus of the state government, privileging the political authority assigned to the CCP over the administrative authority vested in the government (ibid.). According to him, the 1982 Constitution was grounded on two principles. The first is the separation of the CCP apparatus from the state, critical to which is "the need to consolidate and institutionalise Party leadership in a system that leaves room for a state apparatus" (ibid.: 368-9). The second is "to formalize the relationship of apparatus - both State and Party - to law" (Backer 2012: 369), which

69. This is because Professor Jiang has published two papers on this topic in English. Another leading scholar on political constitutional theory is Gao Quanxi (2012: 22-43).

70. China has had written Constitution since 1954, and the 1982 Constitution has already existed for 36 years.

71. Ibid.

72. In addition, Jiang is of the view that constitutional conventions, thoughts of political leaders, and constitutional statutes such as the Basic Law of Hong Kong are other types of unwritten constitutions in China. See Jiang (2010), and also Xie Libin and Haig Patapan (2016: 1012).

73. This is actually the argument of Professor Gao Quanxi, who is another famous scholar advocating this theory. See Gao (2012: 22-43). 
was "realized through the adoption of a constitutional framework for the governance of state and Party" (ibid:: 370). Backer posits that "the principle of constitutionalization in China might best be understood as bifurcated" and "focused both on rule of law institutionalization of the state apparatus combined with a similar institutionalization of Party organization through its own constitution" (ibid.: 370). He suggests that it is important to understand the Chinese constitutional system as being comprised of two documents - the 1982 Constitution and the constitution of the CCP. "The former lays out the organization of the state and the relationship between the state apparatus and the party in power, which remains the holder of supreme collective political authority. (...) The latter organizes and institutionalizes the manifestation of political authority within the nation" (ibid.: 370-1). Backer believes that the state can only be considered complete when the formal state apparatus is joined with the CCP apparatus under the rule of law framework expressed in both the Chinese Constitution and the CCP constitution (ibid.: 372).

For Backer, the relationship between the state normative system and the CCP normative system is hierarchical, with the state apparatus sitting at a lower level while the CCP enjoys supreme political authority (ibid.: 385). He argues that the Chinese model constitutes a unique constitutionalist stateparty in which the CCP as an institutionalised collective "has principal responsibility for constitutional values - for shaping the form and values substance of the rule of law" (ibid.: 396). For him, the CCP as the source of thick rule of law is vested with that function through the Constitution. On the one hand, the CCP is a state institution whose functional role is constrained by the Constitution. On the other, the CCP represents the political power of the people of the state and therefore has an extra-constitutional role (ibid.: 396).

Like Backer, Li also believes the normative system of the CCP is separate from the normative system of the state. In her view, the two normative systems could be compatible or complementary most of the time, since the CCP sanctions state laws. If CCP interests diverge from state interests and CCP regulations are at odds with state laws, the CCP normative system enjoys superior authority (ibid. 2012). Li's main contribution to the theory is on how the normative system of the CCP is integrated with the normative system of the state. For her, the CCP's exercise of power, especially the decision-making process, is separate from that of the state. Instead of a fusion of the CCP and state activities, state decision-making has been bifurcated, with one phase taking place backstage in CCP institutions and the other taking place onstage in state institutions. The bridge between them is provided by the Party-groups installed in state institutions, which serve both the CCP and the state (Li 2015: 106). In this way, while at the controlling end of the decision-making process, CCP activities are isolated and concealed from state activities. As a result, the CCP is shielded from being held accountable for state actions that are taken on the CCP's instructions ( $\mathrm{Li}$ 2015: 106).

\section{Analysis of its applicability}

The theory of a dual normative system is a good attempt to interpret and justify constitutional practice in China. By deeming the CCP constitution an essential component of the constitutional normative system, this theory legitimises the leadership of the CCP. It treats the CCP as a state institution on top of the state apparatus. It also explains well the extraconstitutional/legal role played by the CCP.
One challenge posed to this theory by the new constitutional amendments, especially the supervisory commissions with fused functions in both the CCP and state apparatus, is its claim of separation between the CCP and state apparatus. Both Backer and Li hold the position that there is a division of power and matters between the CCP and the state under the 1982 Constitution and in Chinese constitutional practice thereafter. But the CCP abandoned separation of the CCP from the state apparatus after 1989. The creation of supervisory commissions represents a conflation of both the CCP apparatus and the state apparatus. This trend has continued with the 2018 institutional reform plan, under which many other CCP and administrative organs have merged. (74) This fusion will deepen in the foreseeable future and challenge the persuasiveness of this theory.

A related challenge is the theory's position on the relationship of the decision-making process between the CCP and the state, which suggests that the CCP apparatus acts backstage whereas the state apparatus functions onstage. This may well be the wish of many Chinese scholars, including myself (Lin 2011). If the CCP exercises its leadership through the Party groups, as claimed by Li, that means the CCP is aware of the necessity to operate under the Constitution. But since 1989, the CCP has never shied away from making decisions directly without going through the state apparatus, especially the NPC and NPCSC.

For example, the current round of judicial reform was initiated by the CCP. ${ }^{(75)}$ According to the new white paper on judicial reform, ${ }^{(76)}$ the CCP Committee on Deepening Reform held 19 meetings on judicial reform in 2014 and 2015. ${ }^{(77)}$ The CCP is masterminding the current round of judicial reform. SPC Opinions have been adopted to implement the policies decided by the CCP Committee on Deepening Reform. ${ }^{(78)}$ For the foreseeable future, therefore, the leadership of the CCP is and will continue to be the propelling force for judicial reform in China. The CCP will continue to make decisions onstage rather than backstage. This practice demands adjustment of the theory.

The third challenge is whether the Chinese system of constitutionalism is designed for the normative system of the CCP to function above the law, including the Constitution. This is also the actual claim of political constitutional theorists in China. ${ }^{(79)}$ Only in so doing is it possible to justify the existence of Chinese-style constitutionalism. Otherwise, any inconsistent CCP policies and decisions need to directly face arguments of unconstitutionality as claimed by democratic and normative constitutional theorists. However, whether the CCP actually intends its normative system to be above the Constitution is a questionable proposition. Taking the example of the DICs' authority and their coercive investigative power in fighting rampant corruption, a consensus exists among scholars that this is extra-constitutional/legal (Li 2015: 107). According to the theory of a dual normative system, such extra-constitutional norms are above the Constitution and therefore justifiable. However, the CCP has amended the Constitution by bringing the DICs within the Constitution as supervisory commissions. Furthermore, the CCP has enacted the Supervision Law to legalise this coercive

74. See “深化党和国家机构改革方案” (Shenhua dang he guojia jigou gaige fang'an, Plan on deepening the $\mathrm{CCP}$ and state institutional reform), art. cit.

75. See the introduction in section I of this paper above.

76. For a detailed discussion of current round of judicial reform, see Lin Feng (2018: 81-108); Björn Ahl (2014: 121-39).

77. "Judicial Reform of Chinese Courts," SPC, last modified 3 March 2016, http://english.court gov.cn/2016-03/03/content_23724636.htm, (accessed 31 January 2019).

78. Ibid.

79. See above discussion on political constitutional theory. 
investigative power. ${ }^{(80)}$ This shows that the CCP is aware that its past practice was unlawful and unconstitutional. It has taken positive steps to make those unconstitutional norms constitutional. ${ }^{(81)}$

One positive inference of the above actions is that the CCP doesn't believe that CCP norms should be above the Constitution. However, it can also be counter-argued that the CCP has directly put itself forward by coalescing the Party and state functions and apparatus. By constitutionalising the CCP's power and legalising those once extra-legal measures, the CCP effectively operates above the law. This is indeed quite possible and may represent the actual thinking of the CCP. However, the fact that the CCP has made an effort to constitutionalise and legalise once extra-constitutional/legal measures is evidence that it has at least taken the rule by law approach. It has regarded the law as a tool to be used when it sees fit. For me, such an instrumental approach towards the Constitution and legal norms is better than completely ignoring inconsistency between CCP norms and state norms and openly advocating the supremacy of inconsistent CCP norms above state norms. If an evolutionary approach is taken toward the development of rule of law in China, the law is being taken very much more seriously today than before (Peerenboom 2002: chapter 1-3). Compared with the Mao period, the CCP's consciousness of doing things according to the law has increased considerably. My argument is that the most immediate objective for the development of constitutionalism in China is to ensure that all institutions and powers, including the CCP, are subject to state law. What the CCP has done through the creation of supervisory commissions is a step in the right direction. Once this is achieved, the next step is for China to move to the thin rule of law by satisfying its minimum threshold criteria (ibid.). The third stage will be the adoption of some sort of thick rule of law. As Peerenboom has argued, the CCP is not monolithic, and there is support for rule of law among senior officials as well as rank-and-file members. The CCP's decisions on whether or not to move toward rule of law are constrained by various factors such as the need to sustain economic growth and attract foreign investment, international pressure, discontent over corruption, as well as the rising domestic demand for rule of law (ibid.). The legalisation of extra-legal measures through the Supervision Law and making the supervisory commissions accountable to the people's congresses result primarily from rising domestic demand for rule of law. ${ }^{(82)}$

In summary, these three challenges cast doubt on the applicability of this theory.

\section{The way forward - adjustment of the existing theories or a new theory?}

The political constitutional theory acknowledges the political reality in China and treats the leadership of the CCP and its norms as either above the Constitution or as an integral part of its constitutional system. As a result, whatever has been decided by the CCP will be constitutional according to this theory. Since the actual effect of this theory is to blindly endorse any decisions taken by the CCP, it is not really appealing to those who would like to see the Chinese constitutional system develop in a way that satisfies at least the minimum criteria of the thin rule of law theory. Even Professor jiang himself realises the necessity of maintaining a critical attitude towards Chinese constitutional problems and has suggested amendments to the Constitution that include rules about the transfer of power and that put the CCP under the supervision of the Constitution (Jiang 2010: 41-2). While acknowl- edging the usefulness of this theory in justifying China's constitutional practice, it is also its main weakness, as no pressure exists under this theory to make China move towards even thin rule of law. The best approach is to treat this theory as one with value for present-day China, which is still in transition from rule by law to thin rule of law. Once China moves beyond the rule by law stage, this theory will lose its value and should be abandoned.

The theory of a dual normative system seems better and more sophisticated as it not only attempts to justify the leadership of the CCP within the Chinese constitutional system but also explains the interaction between state legal norms and CCP norms. However, as analysed above, this theory also faces serious challenges raised by the 2018 constitutional amendments. Dualism, which is the core of this theory, is in direct conflict with the intention behind the 2018 constitutional amendments, i.e., more fusion of the CCP with the state. The continuing effort to integrate CCP and state organs through the 2018 institutional reform makes this theory less and less convincing.

There seem to be two ways forward. The first is to go back to normative constitutional theory by adopting an evolutionary approach to the development of constitutionalism in China. As discussed above, the 2018 constitutional amendments prove that China is still at the rule by law stage and may gradually develop into a thin rule of law stage. But this approach won't appeal to political constitutional theorists. The second approach is to develop a new constitutional theory that can better explain the 2018 constitutional amendments and the subsequent trend of fusion. Developing such a theory is beyond the scope of this article, besides which the author is not a political constitutional theorist.

\section{Conclusion}

This article has discussed two main issues relating to the 2018 constitutional amendments; one is their significance, and the other is their impact upon two existing interpretative theories of the constitutional reality in China. With regard to the first issue, this article has argued that although abolition of term limits on the President of State and incorporation of the CCP leadership into Article 1 of the Constitution have attracted wide attention and criticism, the two controversial amendments will not cause much practical change to the constitutional structure or its operation in China. Accordingly, they are of neither theoretical nor practical constitutional significance. The creation of the new constitutional organ of supervisory commissions merges another set of CCP organs with state organs and constitutionalises the functions performed by the DICs. This constitutional amendment is likely to cause significant change to both the constitutional structure and its operation in China. This amendment also raises new constitutional issues such as the nature of the supervisory power, the relationship between supervisory commissions and other state organs, and the future Party-state relationship.

However, these three constitutional amendments have sent out a bad signal. In addition, since there is lack of periodic evaluation of the President of State through genuine general elections, the abolition of the term limit together with the emphasis on the CCP's leadership and merging more Party and state organs will facilitate making life-long presidency a reality

80. See Article 22 of the Supervision Law.

81. The CCP has taken a formalistic approach towards rule of law on this issue.

82. The draft Supervision Law contained no provisions to make supervisory organs accountable to the people's congresses. Because of strong domestic criticism and demand, such provisions were eventually incorporated into the Supervision Law. 
and move China further away from rule of law at the constitutional level. With regard to the second issue, this article has discussed the political constitution theory and the theory of a dual normative system. The above analysis shows that the political constitution theory can still explain the constitutional reality. However, this theory gives a blind endorsement to any decisions taken by the CCP. The adoption of this theory serves no purpose other than to legitimise the leadership of the CCP. Since an increasing number of people in China - not only scholars, but also millions of people who have been trained to believe in rule of law, as well as the rising middle class - expect China to gradually embrace rule of law, the author of this paper argues that this theory has historical limitations and is only suitable for presentday China, which is still in its transition from rule by law to rule of law.

The theory of a dual normative system has been a good attempt to justify and interpret the constitutional reality in China. It has legitimised the leadership exercised by the CCP and adequately explains the extra-constitutional role played by the CCP. But the creation of the new constitutional organ of supervisory commissions challenges some core assumptions of this theory, such as the separation of the CCP apparatus from the state apparatus, the separation of CCP matters from state matters, and the intention for the normative system of the CCP to function above the state normative system. Since dualism is the core of this theory, and the 2018 constitutional amendments and subsequent trend of fusion make this theory less and less persuasive.

The Party-state relationship in China has moved one step closer to a constitutionalised fused system, rather than to a dual normative system. The new constitutionalised fused system differs from the old fused system before the CCP came to power in China in that the fused power is subject to the state constitutional and legal system. This article argues that this new fused system challenges theorists of Chinese constitutionalism to come up with a new theory that can better explain new constitutional developments in China. Any new theory should serve not only the purpose of justifying constitutional practice in China but also the purpose of pushing China towards at least the thin rule of law.

I Lin Feng is Professor of Law at the School of Law and Director of the Centre for Judicial Education and Research, City University of Hong Kong (lwlin@cityu.edu.hk).

Manuscript received on 11 May 2018. Accepted on 18 January 2019. 


\section{References}

AHL, Björn. 2014. "Retaining Judicial Professionalism: The New Guiding Cases Mechanism of the Supreme People's Court." The China Quarterly 217(March): 121-39.

BACKER, Larry. 2012. "Party, People, Government and State: On Constitutional Values and the Legitimacy of the Chinese State-Party Rule of Law System." Boston University International Law Journal 30: 331-408.

BACKER, Larry, and Keren WANG. 2014. "The Emerging Structures of Socialist Constitutionalism with Chinese Characteristics: Extra-judicial detention and the Chinese Constitutional Order." Pacific Rim Law \& Policy Journal 23(2): 251-341.

CHEN, Duanhong 陈端洪. 2008. “论宪法作为国家的根本法与高级法” (Lun xianfa zuowei guojia de genbenfa yu gaojifa, On the constitution as a country's fundamental law and higher law). Zhongwai faxue 中外法学 (Peking University Law Journal) 20(4): 485-511.

CHEN, Sixi 陈斯喜, and LIU Songshan 刘松山. 2001. “宪法确立国家中央军 事委员会的经过" (Xianfa queli guojia Zhongyang junshi weiyuanhui de jingguo, The process of the establishment of the CMC by the constitution), Faxue 法学 (Law Science) 2: 3-6.

GAO, Quanxi 高全喜. 2012. “政治宪法学的兴起与嬗变” (Zhengzhi xianfa xue de xingqi yu shanbian, The Rise and evolution of political constitutionalism). Jiaoda faxue 交大法学 (SJTU Law Review) 1:22-43.

HE, Xin. 2012. "The Party's Leadership as a Living Constitution in China." Hong Kong Law Journal 42(1): 73-93.

JIANG, Shigong. 2010. "Written and Unwritten Constitutions: A New Approach to the Study of Constitutional Government in China." Modern China 36(1): 12-46.

JIANG, Shigong. 2014. "Chinese-Style Constitutionalism: on Backer's Chinese Party-State Constitutionalism." Modern China 40(2): 196-213.

LI, Ling. 2015. "'Rule of Law' in a Party-State: A Conceptual Interpretative Framework of the Constitutional Reality of China." Asian Journal of Law and Society 2(1): 93-113.

LIN, Feng. 2000. Constitutional Law in China. Hong Kong: Sweet \& Maxwell Asia.

LIN, Feng 林峰. 2011. “中国的宪政之路：如何从立宪走向宪政?” (Zhongguo de xianzheng zhi lu: Ruhe cong lixian zouxiang xianzheng? China's road to constitutionalism: How to move to the enactment of a constitution to constitutionalism?). In Lin Feng 林峰 (ed.), 百年憲政與中國憲政的 未來 (Bainian xianzheng yu Zhongguo xianzheng de weilai, Constitutionalism in China in the last 100 years and its future). Hong Kong: City University of Hong Kong Press. 243-77

LIN, Feng. 2018. "The Future of Judicial Independence in China." In H.P. Lee and Marilyn Pittard (eds.), Asia-Pacific Judiciaries: Independence, Impartiality and Integrity. Cambridge: Cambridge University Press. 81-108.

MA, Huaide 马怀德. 2017.“国家监察法” 的立法思路与立法重点” (“Guojia jianchafa" de lifa silu yu lifa zhongdian, The legislative thinking and focus of "State Supervision Law"). Huanqiu falü pinglun 环球法律评论 (Global Law Review) 2: 5-16.
ORGAD, Liav. 2010. "The Preamble in Constitutional Interpretation." International Journal of Constitutional Law 8/4(October): 714-38.

PEERENBOOM, Randall. 2002. China's Long March Toward Rule of Law. Cambridge: Cambridge University Press.

QIN, Qianhong 秦前红. 2017a. “监察体制改革的逻辑与方法” (Jiancha tizhi gaige de luoji yu fangfa, Logic and method of supervision system reform). Huanqiu falü pinglun 环球法律评论 (Global Law Review) 2: 17-27.

QIN, Qianhong 秦前红. 2017b. “全国人大常委会授权与全国人大授权之关 系探讨一以国家监察委员会为研究对象” (Quanguo renda changweihui shouquan yu quanguo renda shouquan zhi guanxi tantao: yi guojia jiancha weiyuanhui wei yanjiu duixiang, The Relationship between authorization by the NPCSC and authorization by the NPC: A study of State Supervision Commission). Zhongguo falü pinglun 中国法律评论 (China Law Review) 2: 24-31.

SAPIO, Flora. 2008. "Shuanggui and Extralegal Detention in China." China Information 22(1): 7-37.

TONG, Zhiwei 童之伟. 2016. “将监察体制改革全程纳入法治轨道之方略” (Jiang jiancha tizhi gaige quancheng naru fazhi guidao zhi fanglüe, Methods to include the whole process of supervision system reform within rule of law). Faxue 法学 (Law Science) 12: 3-13.

WANG, Hanbin 王汉斌. 2012. 王汉斌访谈录一亲历新时期社会主义民主 法制建设 (Wang Hanbin fangtanlu: qinli xinshiqi shehuizhuyi minzhufazhi jianshe, Wang Hanbin's interview records: Experiencing socialist construction of democracy and legal system in the new era). Beijing: Zhongguo minzhu fazhi chubanshe.

XIAO, Weiyun 肖蔚云. 2004. 论宪法 (Lun xianfa, On Constitution). Beijing: Beijing daxue chubanshe.

XIE, Libin, and Haig PATAPAN. 2016. "Contesting Legitimacy in China:The Politics of Law in Modern Chinese Jurisprudence." Hong Kong Law Journal 46(3): 991-1016.

YIN, Xiaohu 殷啸虎, and LI Li 李莉. 2004. “宪法序言的功能与效力研究” (Xianfa xuyan de gongneng yu xiaoli yanjiu, On purpose and effect of constitution preamble). Shanghai jiaotong daxue xuebao: Zhexue shehui kexue ban 上海交通大学报: 哲学社会科学版 (Journal of Shanghai Jiaotong University (Philosophy and Social Sciences)) 12(6): 14-9.

ZHANG, Qianfan. 2010. "A Constitution without Constitutionalism? The Paths of Constitutional Development in China." International Journal of Constitutional Law 8(4): 950-76.

ZHAO, Guilong 赵贵龙. 2010a. 中国历代监察制度 (Zhongguo lidai jiancha zhidu, Supervision system in the Chinese history). Beijing: Falü chubanshe.

ZHAO, Suisheng. 2010b. "The China Model: Can It Replace the Western Model of Modernization?" Journal of Contemporary China 19(65): 41936. 